\title{
Digital models applied to the analysis, intervention and management of architectural heritage
}

\author{
R. Angulo Fornos \\ Department of Architectural Graphic Expression, \\ Research Group HUM799, University of Seville, Spain
}

\begin{abstract}
The new technologies spawned by the evolution of CAD constitute the fundamental basis for the investigative work of Research Group HUM799. Based on different methods for conducting architectural surveys, they may give rise to graphical models that are not only capable of assisting dynamic processes of architectural heritage intervention, management and dissemination but are veritable repositories of information about the building. Our main aim here is to experiment with these tools as part of a specific case study of the chapel of La Virgen de la Antigua in Seville Cathedral and find ways to facilitate the generation of all the possible relationships between the data - morphological, material, structural, historical, cultural, etc. - captured from and recorded about this building, and not only based on the materiality of its massive and precursory elements but also on all the elements associated with the immateriality of its spaces (traces, relationships, functionality, accommodation of furnishings, etc.). The scope of this paper is therefore to share a few reflections on the generation of an experimental model for its future use in various disciplines, from heritage management and conservation to intervention, investigation and dissemination. Keywords: BIM, architectural heritage, management, conservation, intervention, dissemination.
\end{abstract}

\section{Introduction}

Since the advent of the theoretical consideration of architecture as cultural heritage, in Italy in the first half of the 20th century, the relationship between our present and historical forms, and in general all forms regarded as having heritage value, 
has revolved around a key issue: knowledge and its inextricable association with the generic aim of appropriate conservation [1]. This knowledge is characterised according to a purely physical dimension - the object itself - and an intangible dimension - its cultural significance.

The interpretation of architectural forms has evolved over time from their description and promotion exclusively in relation to universal values classification of types, styles, etc. - to a consideration of their specificity as part of the concrete environments or contexts in which they occur and to which they bear witness. Meanwhile, historical distance implies the consideration of the architectural object as a "document", and it therefore has a dual value: on the one hand it is the principal gateway to sets of meanings whose internal structures we should attempt to clarify by applying different disciplinary approaches and methodologies; on the other, its irreplaceable testimonial value raises the need for strict, scrupulous conservation and the management of the necessary means to achieve this in light of the risk of destroying or altering valuable clues to its meaning which are perhaps hermetic today but may be interpretable in the future. Since then, this situation has demanded the need to conduct research alongside the conservation and management of architectural heritage, which is the subject of increasingly complex analytical approaches. This is reflected in various international charters and declarations, such as the Venice Charter (1964), updated in subsequent restoration charters [2], and in the national and regional standards and legislation that have followed them.

As a response to this context, this paper presents some of the results obtained from the creation of a digital model that may be used in relation to architectural heritage in order to facilitate an interpretation of its complexities. The model is designed to act as an open-ended and constantly updated system that offers a threedimensional view of the strict physical reality as well as providing all the necessary information to permit a detailed knowledge of the object and therefore assist with decisions regarding conservation strategies, structural calculations, environmental assessments, etc. The construction of this model should not simply aim to reproduce the current physical reality but should be conceived in a multidisciplinary scientific environment that encourages an ongoing debate and in which research into the heritage object is reconciled with the issues surrounding a knowledge model based on digital resources.

Digital models offer a fundamental advantage in this field of study in that they allow researchers to visualise aspects of architecture which more traditional vehicles of expression - orthogonal projections, floor plans and sections - do not permit because they are too coded or abstract. This greatly facilitates the functional convergence of scattered and disjointed information from different fields of knowledge: documentary, archaeological, visual, analytical, economic, technical, reports, etc. We have brought together researchers and professionals related to heritage so that they can contribute solid theoretical knowledge and long practical experience. In terms of technological resources, the research group is applying building information modelling (BIM) systems to heritage properties. Consequently, our aim is not to create a tool that absorbs and classifies all the available information in an automatic, sterile manner, but rather to create an active 
entity that generates knowledge above and beyond disciplinary contributions, that sheds light on the complexity of the property, and that facilitates its appropriate dissemination, all thanks to new technologies, Figure 1.

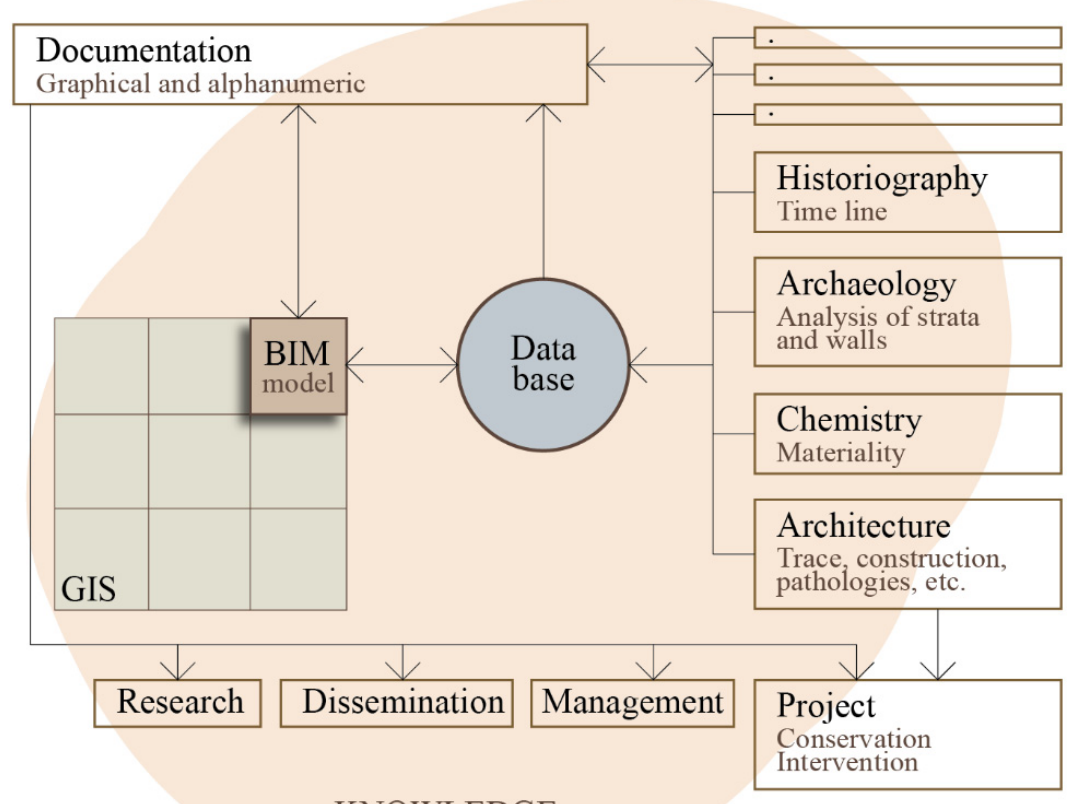

KNOWLEDGE

Figure 1: $\quad$ Proposed information structure.

\section{Case study}

This paper explores a set of results and thoughts based on the digital model currently being generated for the Chapel of La Virgen de la Antigua, a funerary building that forms part of Seville Cathedral, Figure 2.

The Gothic cathedral was built between 1433 and 1506 on the site of the city's old Moorish mosque and within its rectangular perimeter, giving rise to one of the largest Gothic cathedrals in existence. A key element of this mosque was the area where the mihrab was located, in the geometric centre of the rectangular floor plan with its north-south orientation. This small, symbolic space was abutted to a complex system of parallel walls between which was built the sabat (secret passage) separating the mosque from the old alcázar, or fortress. All of these structures were originally integrated into the Gothic building, abutted to its south wall, until they were demolished to make way for the Chapel of La Virgen de la Antigua, which was one of the chapels along the south side of the cathedral nave and aisles, near the transept. 


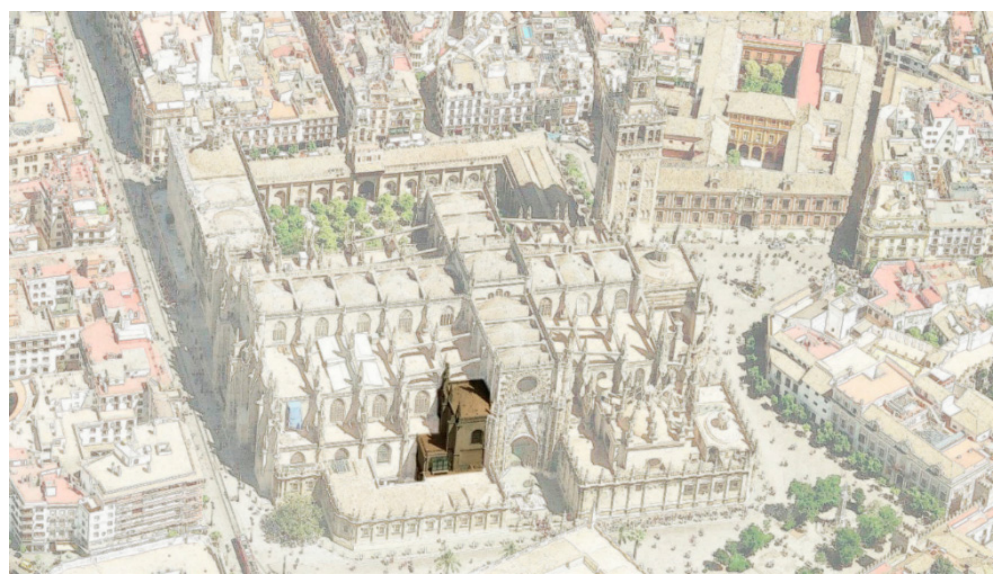

Figure 2: Situation. Aerial view. Image by the author based on Bing Maps (CMS Corporation).

The Chapel of La Virgen de la Antigua that we see today has a rectangular floor plan, following the duplication in height and depth of the original chapel which gained two more spaces: an upper storey to house the library and store musical instruments, and a lower storey to serve as the chapel sacristy. These two superimposed spaces were abutted to the chapel's west wall, a complex extension that took place before the Gothic building had been completed. They were commissioned by Archbishop Diego Hurtado de Mendoza and designed by the architect Simón de Colonia in 1496. In 1502, when their sponsor passed away, the alterations to the remains of the mihrab and sabat were well underway. To gain extra depth, the outer wall of the original chapel was demolished along with a large volume that served as a buttress at the end of the transept and also contained a spiral staircase, affecting the original layout of the cathedral as viewed from the south.

These alterations took place between 1496 and 1512 and were followed by several additional renovations and restructuring exercises, each of which have left a plethora of contractual documents, reports and ledger books, as well as traces and marks where walls have been joined, which have been analysed from the historiographical - Jiménez [3], architectural - Jiménez [4], and archaeological Tabales and Jiménez [5], Mora and Guerrero [6] - perspectives in the case of the building still visible - walls and roofs - and have been the subject of geophysical prospections to identify hidden remains. These latter references have provided the basis for writing this section of the document.

In short, this building is the result of the complex alterations and renovations that have taken place through the years, which paradigmatically have given rise to an edifice characterised by an immense unity of form. Deciphering the changes that have occurred and the building processes involved may shed light on how its form evolved and why certain decisions were taken, as well as helping to identify the weak points that have arisen from these changes. From a methodological point of view, the construction of the digital model enables us to visualise 
simultaneously all the information pertaining to the various stages of the building, some of them concealed by subsequent phases, and to explain some of the discontinuities of form that could not be fully understood from stylistic interpretations alone.

\section{Development of the digital information model}

Continuing with the discourse presented in the introduction, the need to create a BIM model of the object of study is based on considering:

- The architectural object as a document in itself, a bearer of extremely diverse information which clearly needs to be recorded in the model.

- That architectural heritage has been subjected to a complex process of transformation - materials, rheology, social and cultural conditions - over the years, and these also need to be recorded and evaluated.

- That this process of transformation will be ongoing, because any interpretation of this heritage or any intervention in it will be performed from a specific cultural standpoint. The review of the data recorded and their interpretation is therefore of crucial importance in order to prevent the loss of information.

- That the convergence of diverse fields of knowledge must be the pivot around which the entire process revolves, and its ultimate aim must be to provide a versatile tool to assist heritage research, conservation, intervention and dissemination.

In this respect, the BIM model will be a live "drawing" of the building, although it can never replace the reality. It will always be an abstraction derived from the deliberate, carefully delimited selection of information captured directly from the object and completed through contributions of interdisciplinary knowledge.

Consequently, on the scale of the architectural object, the BIM could take the same form as that which characterises GIS, as a tool that offers classified or filtered information which, fed continually from the input data, provides new visions or three-dimensional approaches that help to form knowledge based on the graphical representations generated. In other words, it will be treated as a database, available for constant consultation - graphical, topical or alphanumeric - and its answers will lead to new knowledge and, therefore, to the ability to perform analyses that assist with the interpretation and comprehension of the hidden details of its transformation over the years. These visions would be very difficult to obtain directly from alphanumeric information alone.

The use of BIM is not a new methodological approach for this research group, Angulo [7], but this is the first time we have used to it analyse a "complete" and relatively complex architectural object and the first time that the data captured and recorded are not only based on the materiality of its massive and precursory elements - morphological, material, structural, historical, cultural, etc. - but also on those associated with the immateriality of its spaces, such as its traces, relationships, functionality, accommodation of furnishings, etc.

In recent years there have been many contributions in this respect as regards to the general scope of existing buildings, such as those provided by Volk et al. [8], but few in the specific field of heritage architecture, the most notable being those 
of Simeone et al. [9], Murphy et al. [10], Rua and Gil [11], and Nieto Julián and Moyano Campos [12]. In these investigations the model is treated solely as the reflection of its current physical reality, on a material and documentary level. However, we believe that it should also serve as a repository for all the related elements, from excavations, documents, etc. that provide a diachronic interpretation of the building and permit spatial analyses that would be very difficult to perform without these models.

\subsection{Model structure}

With regard to the generation of the various elements and the systematisation of the information they contain or to which they are linked, the digital model adopts a stratigraphic structure composed of different material layers, Figure 3.

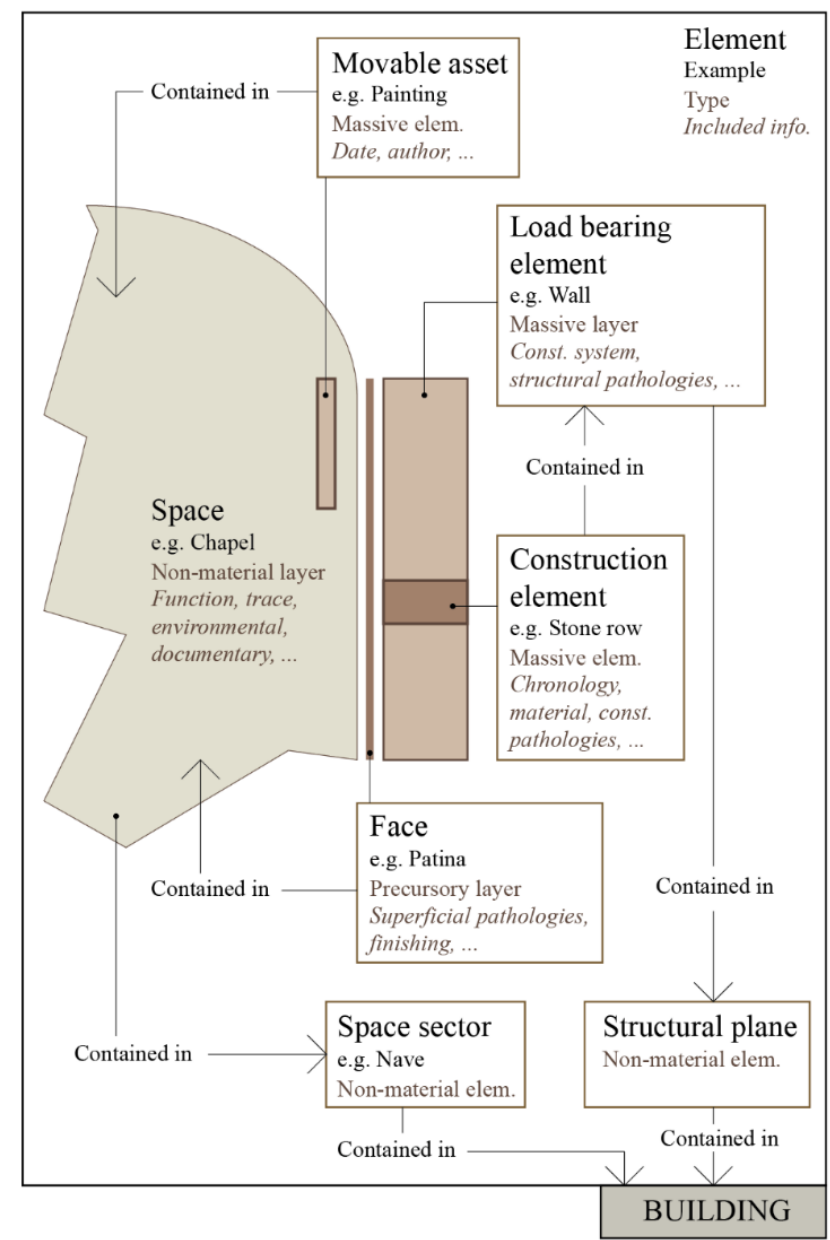

Figure 3: Digital model structure. 
Thus, we pass from the immateriality of the spaces, containers of other objects - such as movable assets - and information related to functional and environmental aspects as well as analytical information regarding aspects such as its geometric trace, to the massive strata usually composed of building elements containing data about their materiality and information concerning their time line, obtained from historiographical and archaeological studies. In between these layers a very thin precursory layer is introduced which may contain any type of information, measurable or not, of a superficial nature, such as pathological aspects or those related to the materiality of the wall finishes or patina. Consequently, through the deliberate management of the use of filters and consultations of the data recorded, it is possible to generate analytical images that offer a direct visualisation of the different relationships between the data processed.

\subsection{Choice of software}

Any BIM software on the market would have provided us with sufficient tools to undertake this experiment quite satisfactorily, barring the persistent difficulties of using applications originally designed for new works of architecture or their renovation but not for historical architecture. These difficulties are the nonexistence of families of parametric elements related to old buildings that can also be extrapolated to universal information sharing formats such as IFC.

On this occasion we have opted to use Autodesk ${ }^{\circledR}$ Revit due to its versatility for managing and modelling complex forms, and to the possibility of combining it with Autodesk ${ }^{\circledR}$ Dynamo, an open source graphical programming software which offers a very powerful option not only for creating graphical representations of complex geometries but for managing the information flows between the BIM model and the database both efficiently and automatically.

\subsection{Input data}

Graphic surveys of heritage architecture have tested all the available tools for capturing the dimensions and forms of the architectural object, confirming that none of them is valid if the ultimate aim is to capture the entire complex reality of the object but all of them are valid if it is merely a question of obtaining information for a specific purpose.

One of the premises of this investigation should be to generate a rigorous model from the point of view of the object's dimensions and forms so that its geometry is capable of recreating a sufficiently accurate visualisation of any defects in the building system - to the extent of providing useful information for its structural analysis - and offers a reliable source of graphical information for future maintenance and interventions in the architecture. This required the use of techniques for capturing large volumes of data or performing reverse engineering.

In this case we opted to capture point clouds using digital photogrammetry outside, Figure 4, and laser scanning inside where poor lighting prevented the use of the former method. 


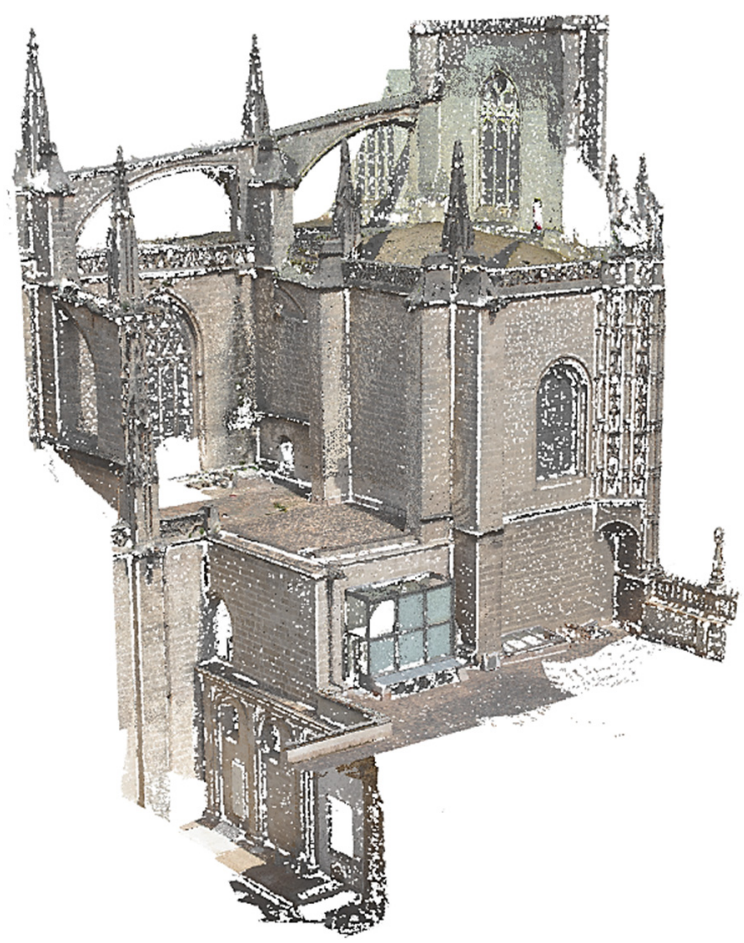

Figure 4: Photogrammetric survey of the exterior.

\subsection{Modelling process}

One of the greatest determining factors when it comes to using these types of models with heritage objects is the complete lack of geometry in certain elements, either because they are buried or semi-derelict structures or they are elements that have undergone deformations due to static or dynamic forces over time. The decision usually lies between two parallel methods or paths: the formal generation of the object by translating the digital capture of points into a closed mesh of triangles for conversion into a classifiable generic mass in the BIM environment, or the geometric interpretation - with a certain threshold of accuracy - of the point cloud to obtain the generative layout of an adaptive parametric element with greater potential for contributing and containing information than a generic mass.

In the case study, the first option was inevitable for the structures exposed by archaeological investigations into the subsoil, which will form an important part of the model in terms of its diachronic analysis. But for all the other elements, such as the rib vault, we have used the second option, obtaining from the digital capture, through 3D modelling software, the requisite graphical elements - NURBS surfaces for superficial elements and curves and sections for linear elements, Figure 5 - to generate spatial, massive and precursory parametric elements, Figure 6. 

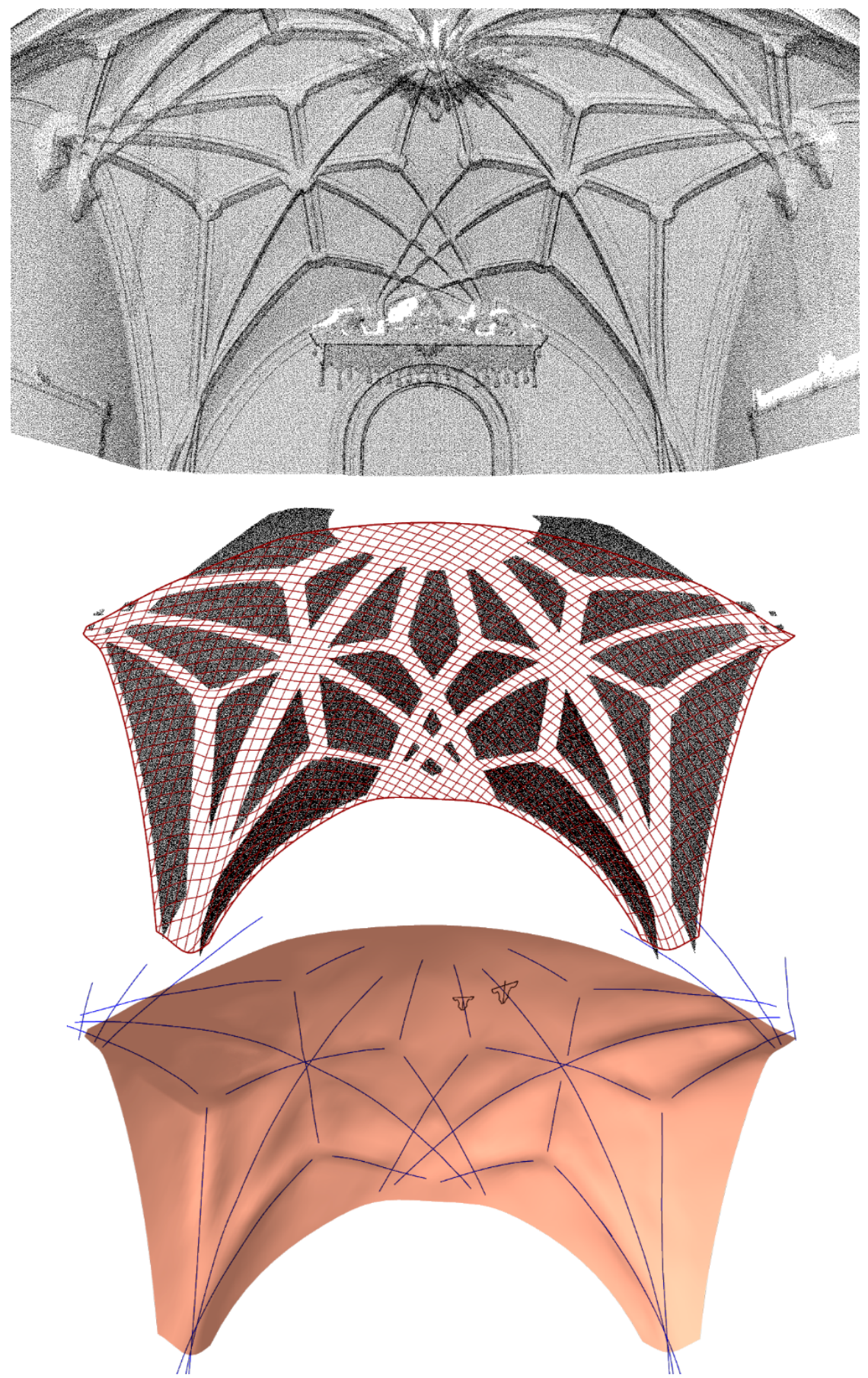

Figure 5: Rib vault. Geometry obtained from point cloud. 


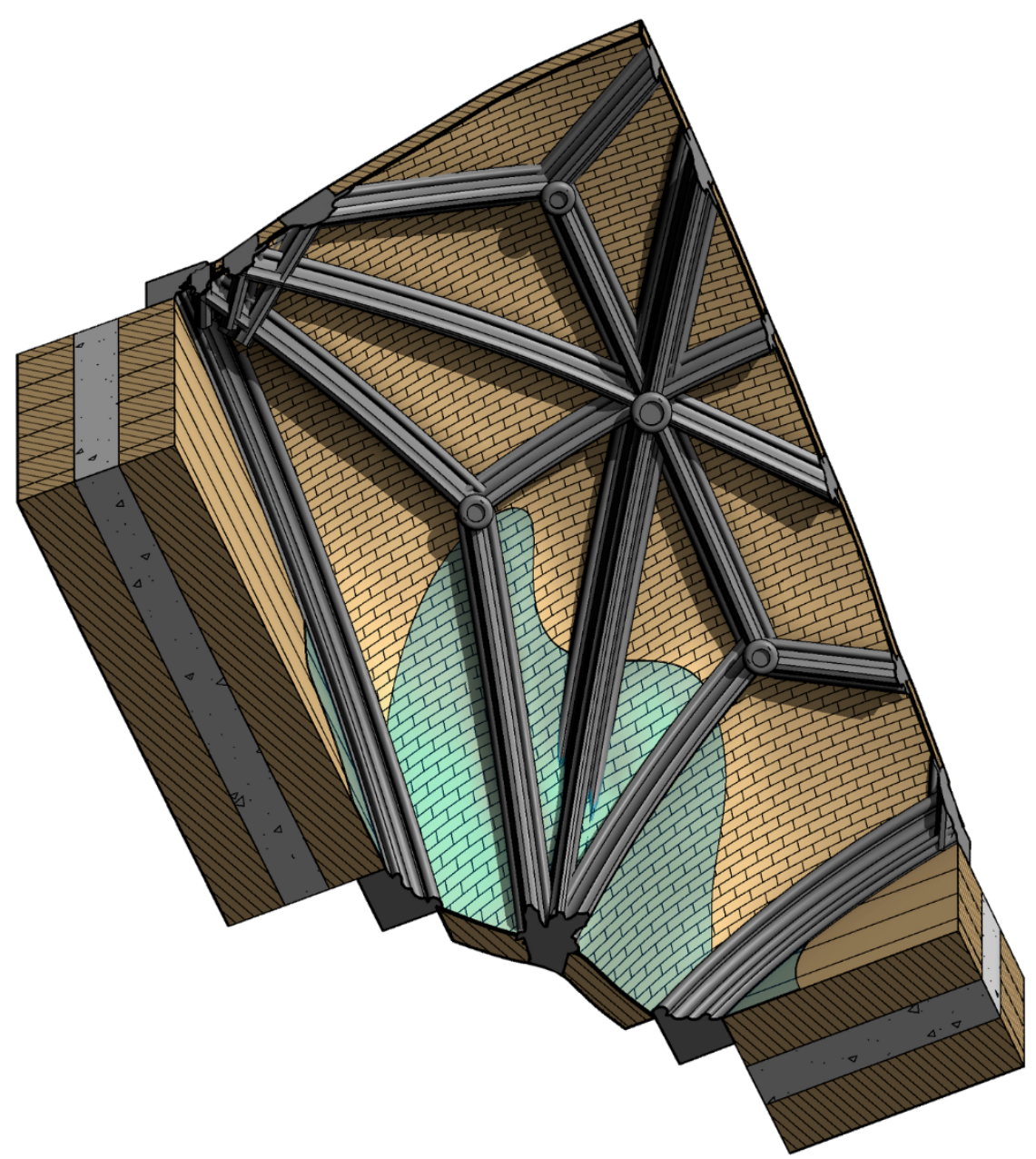

Figure 6: Rib vault. Digital model at the development stage.

The building model is currently being completed and work has begun on developing the database that will interact with the model. The modelling process has been satisfactory in general, but investigations continue into how to improve the processes for generating highly complex forms - such as the springing lines of rib vaults - by interpreting how they were built. In any case, this first phase has resulted in a number of interesting conclusions.

\section{Conclusions}

A unique characteristic of heritage architecture is its consideration as the result of a long process of renovations and transformations over time, even if on many occasions the final consequence has been a building with enormous unity of form. 
The use of digital models is proving particularly interesting in these cases because the synchronous visualisation of different stages of the building's history permits a much more accurate interpretation of its temporal fragments. In this case, this aspect was developed by implementing in the model the possibilities offered by the software used to classify the elements into different phases.

This experience is successfully proving one of the principal advantages of BIM models, which is that they evolve with the actual analysis of the heritage object in question: in other words, from the moment its merits are recognised and protected under the aegis of some form of legal regulation, its inclusion in a catalogue or inventory of protected assets, to its profound study, restoration or formulation of plans for its future conservation.

This evolution can be compared to the LOD (Level of Detail) specifications that have become a standard component of BIM systems applied to new buildings and that are not only serving to amortise the time and financial investment in creating them but guaranteeing their efficiency in accordance with the aforementioned principles of functional convergence.

Finally, in relation to the actual process of generating the digital model, it has become even more evident that you can only "draw what you know", a very widespread expression in the teaching of drawing. Thus, as the model evolved, in its consideration as an "infographic" image, it became increasingly clear that the process must be accompanied by constant interdisciplinary debate, continual feedback about the drawing/object, in order to guarantee the correct interpretation of the aspects that influence the building and spatial origins of the architectural object.

\section{Acknowledgement}

Related to project HAR2012-34571 funded by the Spanish Ministry of Economy and Competitiveness and led by the lecturer Francisco Pinto Puerto.

\section{References}

[1] Brandi, C., Teoría de la Restauración, Alianza Editorial: Madrid, 1988.

[2] ICOMOS, www.icomos.org/en/; CIPA, cipa.icomos.org

[3] Jiménez, A., Rarezas de la Capilla de la Antigua de la catedral de Sevilla, Actas del Simposium internacional sobre la catedral de Sevilla en el contexto del gótico final, Dereçeo: Seville, pp. 401-420, 2007.

[4] Jiménez, A., Anatomía de la Catedral de Sevilla. Diputación Provincial de Sevilla. Seville, 2013

[5] Tabales, M.A. \& Jiménez, A., La Cilla de la Catedral y el sector meridional de la mezquita aljama de Sevilla, Magna Hispalensis (I) Recuperación de la aljama almohade, Cabildo catedral: Seville, pp. 229-296, 2002.

[6] Mora, G. \& Guerrero, J.M., La capilla de Nuestra Señora de la Antigua de la Catedral de Sevilla en el tránsito al siglo XVI. Una aproximación desde el análisis constructivo, estratigráfico y documental, Actas del II Congreso 
Internacional Sevilla, 1514. Arquitectos tardogóticos en la Encrucijada, Univ. Sevilla-Univ. Cantabria (press article).

[7] Angulo, R., Construcción de la base gráfica para un sistema de información y gestión del patrimonio arquitectónico: Casa de Hylas, Arqueología de la arquitectura, 9, pp. 11-25, 2012.

[8] Volk, R., Stengel, J., \& Schultmann, F., Building Information Modelling (BIM) for existing buildings - Literature review and future needs, Automation in Construction, 38, pp. 109-127, 2014.

[9] Simeone, D., Cursi, S., Toldo, I., \& Carrara, G., B(H)IM - Built Heritage Information Modelling. Extending the BIM approach to historical and archaeological heritage representation, eCAADe, Vol. 1, pp. 613-622, 2009.

[10] Murphy, M., McGovern, E., \& Pavia, S., Historic Building Information Modelling - Adding intelligence to laser and image based surveys of European classical architecture, ISPRS Journal of Photogrammetry and Remote Sensing, 76, pp. 89-102, 2013.

[11] Rua, H., \& Gil, A., Automation in heritage - Parametric and associative design strategies to model inaccessible monuments: The case-study of eighteenth-century Lisbon Águas Livres Aqueduct, Digital Applications in Archaeology and Cultural Heritage, 1(3-4), pp. 82-91, 2014.

[12] Nieto Julián, J. E., \& Moyano Campos, J. J., The paramental study on the Model of Information of Historic Building or "HBIM Project", Virtual Archaeology Review, 5, pp. 73-85, 2014. 